\title{
Governance structures in cooperative slaughterhouses: a study on the chain of differentiated beef in the state of Paraná ${ }^{1}$
}

\author{
Estruturas de governança em cooperativas de abate: um estudo na \\ cadeia da carne bovina diferenciada no Estado do Paraná
}

Jaiane Aparecida Pereira ${ }^{1}$ (D) Amanda Ferreira Guimarães ${ }^{2}$ (D), Rejane Heloise dos Santos ${ }^{1}$ (D), Sandra Mara de Alencar Schiavi² (i), José Paulo de Souza² (i)

${ }^{1}$ Universidade Federal do Mato Grosso do Sul (UFMS), Naviraí (MS), Brasil. E-mail: jaiane.pereira@ufms.br ${ }^{2}$ Graduation Program in Administration, Universidade Estadual de Maringá (UEM), Maringá (PR), Brasil. E-mails: amandafguimaraes@live.com; rejaneheloise@hotmail.com; smaschiavi@uem.br; jpsouza@uem.br

\begin{abstract}
How to cite: Pereira, J. A., Guimarães, A. F., Santos, R. H., Schiavi, S. M. A., \& Souza, J. P. (2022). Governance structures in cooperative slaughterhouses: a study on the chain of differentiated beef in the state of Paraná. Revista de Economia e Sociologia Rural, 60(1), e233496. https://doi.org/10.1590/1806-9479.2021.233496
\end{abstract}

\begin{abstract}
This study sought to discuss the governance structures adopted between livestock producers and their cooperative slaughterhouses in the chain of differentiated beef in the state of Paraná. The theoretical basis used was the Transaction Cost Economics and Measurement Costs Economics, complemented by the specificities of cooperatives. We conducted interviews with three key agents and eleven representatives of six cooperative slaughterhouses operating in this system. As result, we observed that the cooperatives have similar objectives and requirements, although there are differences in the levels of formality or flexibility. Although transactions are recurrent and have been successful, they involve a high asset specificity, depend on subjective measurements, and are still exposed to market uncertainties, which leaves room for the generation of conflicts and disincentives to quality. Despite this, the relational and reputational aspects associated with trust and partnership between the parties are elements that enable reduced transaction and measurement costs in these structures. At first, the measurements conducted by the cooperatives had an important role in the construction of trust between the parties and for value distribution. In a second moment, the trust built enabled the reduction of measurement costs.
\end{abstract}

Keywords: coordination, cooperative, hybrid forms, differentiation, beef cattle.

Resumo: O objetivo deste trabalho foi discorrer sobre as estruturas de governança adotadas entre pecuaristas e suas cooperativas de abate na cadeia da carne bovina diferenciada no Estado do Paraná. Utilizou-se como base teórica a Economia dos Custos de Transação e a Economia dos Custos de Mensuração, complementadas pelas especificidades das cooperativas. Foram realizadas entrevistas com três agentes-chave e onze representantes de seis cooperativas de abate atuantes nesse sistema. Como resultados, observou-se que as cooperativas possuem objetivos e exigências semelhantes, embora haja diferenças nos níveis de formalidade ou flexibilização. Constata-se que, embora as transações sejam recorrentes e tenham sido exitosas, envolvem elevada especificidade de ativos, dependem de mensurações subjetivas e ainda estão expostas a incertezas de mercado, o que deixa margem para geração de conflitos e desincentivos à qualidade. Apesar disso, os aspectos relacional e reputacional associados à confiança e parceria entre as partes se constituem como elementos que possibilitam a redução dos custos de transação e de mensuração nessas estruturas. As mensurações realizadas pelas cooperativas tiveram um importante papel na construção da confiança entre as partes e para a distribuição de valor, em um primeiro momento. Em um segundo momento, a confiança construída possibilitou a redução dos custos de mensuração.

Palavras-chave: coordenação, cooperativa, formas híbridas, diferenciação, pecuária de corte.

\footnotetext{
1 "This study was carried out with the support of the Coordination for the Improvement of Higher Education Personnel - Brazil (CAPES) - Financing Code 001" and of the National Council for Scientific and Technological Development (CNPq) (proc. 471559/2014-8)
} 


\section{Introduction}

The importance of Brazilian agribusiness in the national and international scenario in several sectors is undeniable. The Gross Domestic Product (GDP) of agribusiness, in 2019, corresponded to $21.4 \%$ of Brazilian GDP, and the livestock sector was highlighted for an expressive growth of $23.71 \%$ compared to 2018 (Centro de Estudos Avançados em Economia Aplicada, 2020). Specifically, in beef cattle farming, in 2019, Brazil was the largest exporter of beef and the third-largest considering world production (United States Department of Agriculture, 2020).

Although the performance of Brazilian livestock has been satisfactory, studies show coordination problems, especially when considering the asymmetry of information between agents, compromising competitiveness in this Agro-Industrial System (AGS) (Caleman et al., 2008; Caleman \& Zylbersztajn, 2012; Macedo, 2015; Oliveira et al., 2019; Saab et al., 2009). In addition to coordination failures, rural producers tend to face barriers involving production scale, standardization, and costs, which affect their permanence in the market (Farina, 2002; Hooks et al., 2017; Shanoyan et al., 2019). It should be noted that lack of coordination is a recurring problem in national livestock (Siffert Filho \& Faveret Filho, 1998), which diversity in the quality of meat marketed affects the adequate distribution of earnings in the chain.

In face of these problems, differentiation efforts have emerged in the beef AGS. Differentiation may be linked to the production of a certain breed of cattle, precocious calf, differentiated cuts (Macedo, \& Moraes, 2009; Macedo, 2015) and production systems, such as organic meat (Barbosa \& Caleman, 2016; Caleman et al., 2017). These forms of differentiation may also involve national and international certification programs to attest to superior quality (Forest et al., 2014; Sornberger et al., 2010).

The creation of differentiation can involve efforts in innovations to develop products with greater added value (Tóth, 2015). In the beef production chain, these innovations may be linked to improvements in organoleptic characteristics in the final product (color, flavor, softness, texture), and the production process, through crossing breeds, management forms, precocity, traceability, and socio-environmental and sanitary standards (Hooks et al., 2017; Saab et al., 2009).

This is a context also identified in the state of Paraná, in which the beef chain faces the same problems as the national context, with reduced herds annually. In this case, the search for differentiation and focus on quality directs efforts in the upstream and downstream segments in the chain. Oliveira et al. (2017) show that the organization in collective forms consists of a mechanism that helps the increase of bargaining power and the resolution of conflicts in the beef chain. In agreement with these authors, and in order to improve the relationship between the parties in the beef production chain in the state, actions were developed aimed the creation and promotion of new forms of organization. According to the Instituto Paranaense de Assistência Técnica e Extensão Rural(EMATER - Paraná Institute of Technical Assistance and Rural Extension), one of the ways to leverage the competitiveness of the productive chain of beef cattle in the state is production focused on quality, at the expense of those concentrated in gains in scale and cost. In this context, the organization of producers in cooperatives or alliances was encouraged (Instituto Paranaense de Assistência Técnica e Extensão Rural, 2018).

In Paraná, there are seven arrangements (alliances and/or cooperatives) in the differentiated system, with about 500 livestock farmers and approximately 93 thousand precocious animals slaughtered per year (RIC Mais, 2015; Ueno, 2016). In general, these organizations are formed by groups of producers who establish rules in order to offer a differentiated product. It is worth noting that other attempts to form alliances and cooperatives coordinated by producer groups in other states have not been successful and have been discontinued or have undergone changes over time, such as: the alliance involving the producers of the Gaúcho Quality and Productivity Program; the 
Center of Precocious Calf Producers of Minas Gerais; and the Total Quality Program for Beef of the Livestock Development Fund (FUNDEPEC) of the state of São Paulo (Rocha et al., 2001).

Product differentiation efforts identify, in transactions, specific investments and attributes that may not be easily measurable. Considering the discussions of Williamson (1985) and Barzel (2005), we understand that the survival of these systems requires more complex governance structures than the market. Governance structures are mechanisms that define the way transactions are configured and can occur via market, hierarchy (vertical integration), or arrangements of various forms (hybrid forms) (Williamson, 1985).

Considering the complexity of the beef AGS, given the context shown, and the success of cooperative slaughterhouses operating in Paraná, this study sought to discuss the governance structures, adopted between livestock farmers and their cooperative slaughterhouses, in the chain of differentiated beef in the state of Paraná. Understanding the operational and competitive dynamics involving these specific forms of arrangement (cooperatives and alliances) brings significant contributions to the definition of public and private policies, aimed at leveraging the performance of the activity in general and, particularly, in the state of Paraná. The efficiency in the way of organizing transactions between agents minimizes problems in the direction of strategic actions for the generation of competitive performance aligned with the demands of the domestic and foreign market and existing productive conditions.

In this orientation, to achieve the set goal, the work is organized into five sections. In addition to this one, which is introductory, the second shows the theoretical rationale based on the Transaction Costs Economics (TCE) and Measurements Costs Economics (MCE), complemented by a discussion of the specificities of hybrid forms - cooperatives. The third describes the methodological procedures adopted. The fourth shows and discusses the results of the research. The last section addresses the conclusions.

\section{Transaction Cost Economics and Measurement Cost Economics}

In a scenario in which free functioning of the market was considered efficient, Coase (1937) questioned why a variety of organizational forms existed. The author concluded that there are costs in transacting by the market, which Williamson (1985) later called transaction costs. One of the fruits of Coase's efforts was the strand called New Institutional Economics (NIE), which considers that institutions (values, norms, legal institutions, legal norms, firms) do matter (Joskow, 2004). The advances of this strand became different theories such as TCE and MCE, discussed below.

\subsection{Transaction Cost Economics}

Supported by the contributions of Coase (1937), Williamson (1985), the precursor of TCE, stated that the transactions of an asset involve transaction costs. For the author, transaction costs are costs of exchanging, capturing, and protecting property rights, which are not perfectly protected. The protection of property rights, in turn, presupposes costs and losses of values by the company. Therefore, managers and company strategy play a role: to undertake governance structures that reduce these transaction costs (Williamson, 1985; Saes, 2009).

TCE, according to Augusto et al. (2014), shows transactions as a unit of analysis and aims to control property rights through appropriate governance structures that reduce transaction costs. Williamson (1985) outlines three factors that qualify the transactions: uncertainty, frequency, and specificity of assets. These factors are outlined considering two behavioral assumptions: opportunism and limited rationality. 
Uncertainty, according to Williamson (1985), is related to the concepts of limited rationality and opportunism, without which strategies able to address all the possible obstacles and general rules of behavior would be developed. However, in the presence of these assumptions, companies need to evaluate the alternative attributes of possible governance structures. Thus, the complex economic environment as a whole makes it impossible to make decisions under full certainty, since problems arise and can assume different origins and types, hindering a precise evaluation to accurately assess strategic decision-making (Williamson, 1985).

The frequency of transactions is important to reduce the costs of collecting information, elaborating contracts, and imputing losses to the other party in the event of contract breaches. In addition, it favors the construction and evolution of trust relationships, which forms a reputation and may limit opportunism (Williamson, 1985).

The asset specificity, in turn, concerns special investments performed for a transaction or specific contract, and cannot be redeployed to another transaction without loss of productive value in the event of contract breaches (Williamson, 1985). For Williamson (1991), the possibility of a loss of value is the critical element for the choice of governance structure. The author outlines six types of specificities: locational, temporal; physical assets; human assets; dedicational assets; and brand.

Governance structures follow, according to Williamson (1985), a continuum from market to integration, passing through hybrid forms, as the specificity of assets increases. According to the author, market governance is adequate when there is no asset specificity. In these cases, there is no bilateral dependence, and the contracts cover the content of the transaction (Williamson, 1985).

In cases where there is asset specificity, the most adequate forms of governance may be hybrid forms or vertical integration. Hybrid forms may involve asset specificities when transactions are recurrent. In these cases, the identity between the parties matters, and they care about the continuity of the relationship. Ménard (2004) states that such forms involve long-lasting relationships and are coordinated more efficiently than the market, without the need to integrate vertically. The adoption of hybrid forms involves both coordination and cooperation, since trust has an important role in the reduction of opportunist behavior (Ménard, 2004), as is the case of cooperatives, discussed later.

According to Williamson (1985), hybrid forms comprise inefficiencies in contractual adaptability. For this reason, in cases where there is a high specificity of assets and problems of contractual adaptation, vertical integration becomes adequate (Williamson, 1985).

The different contractual arrangements are not free of cost. On the one hand, the organization outside the company covers costs for elaborating and executing a contract. In this context, vertical integration is an efficient cost mitigation mechanism. On the other hand, vertical integration suffers from bureaucratic and installation costs (Williamson, 1985), as well as rigidity in the face of market changes (Joskow, 2004). Thus, the choice for one or another governance structure is made considering the transaction costs of alternative mechanisms (Joskow, 2004; Williamson, 1985).

\subsection{Measurement Cost Economics}

As an alternative to the proposal of Williamson (1985), Barzel (2005), in MCE, argues that an asset has several dimensions that can be measured and whose measurability can be easier or more difficult. The author is concerned with ensuring the property rights of each of the parties in the transactions. Property rights can be divided into economic right, which refers to the ability to enjoy a good directly or indirectly, and legal right, which consists of the granting of rights through legal mechanisms (Barzel, 2005). Therefore, since distribution depends on the possibility of measuring these dimensions, even under high asset specificity, the possibility of measuring enables less complex governance structures (Barzel, 2005). 
Caleman \& Zylbersztajn (2012) maintain that the fundamental construction of MCE is based on the existence of value captured through the cooperation of the subjects: if there are mechanisms that correctly define and protect property rights, operations will be conducted at a lower cost. However, if property rights are not correctly defined or executed, some value will remain in the public domain and will be subject to capture. Thus, the institutional arrangement observed will represent a mixture of formal institutional protection, associated with legal rights and informal institutional protection, associated with economic rights (Caleman \& Zylbersztajn, 2012).

This way, dimensions that are easy to measure are contracted, and the difficult ones that open up space for the capture of value must remain within the company. The control mechanisms pointed out by Barzel (2005) are risk relationships; contractual relationships; longterm relationships and vertical integration. According to Barzel (2005), each control mechanism differs from the others based on the required information structure.

Risk relationships are appropriate when the dimensions of the asset are easily measurable and possible to be stipulated before the exchange. The legal mechanism supports contractural relationships, which involve attributes that can be measured and contracted but can only during consumption. Attributes that are difficult to verify and subject to subjective measurements require long-term relationships or vertical integration (Barzel, 2005).

Barzel (2000) points out that, when the measurement has high value and measurement in consumption is difficult to verify, long-term relationships are more adequate than contractual relationships. Measurement during consumption is subjective, opening room for losses. In this case, the use of brands, reputation, and trust can minimize transaction costs. Finally, vertical integration is useful when information involves high costs and cannot be accessed even after consumption (Barzel, 2005).

Since hybrid forms involve various types of organizations, the next topic more specifically discusses cooperatives.

\subsection{Hybrid forms - cooperatives}

Hybrid forms involve contractual governance relationships (Williamson, 1985), which can be bilateral or trilateral (Ménard, 2004). They preserve the flexibility and potential incentives that vertical integration restricts and allow for a selective choice of suitable partners, joint planning between parties, and information sharing (Ménard, 2004). Zylbersztajn (2005) elucidates that contracts occur because there are costs in the operation of markets, and the parties to a transaction may prefer to carry out the supply, production, and distribution activities in a coordinated manner, through the contract.

The reasons for the existence of hybrid forms involve investments in the construction of mutual dependence, but keep the decision and property rights separate; and the monitoring of uncertainties, which involves the degree of uncertainty, since the greater the uncertainty, the greater the risk of opportunism and, consequently, the more centralized the coordination of the arrangement becomes (Bouroullec \& Paulillo, 2010; Ménard, 2004).

Several organizational forms are called hybrids, such as clusters, networks, franchises, alliances, cooperatives, and other "strange forms", which have long-lasting relationships and are coordinated more efficiently than the market without necessarily integrating vertically (Ménard, 2018). Bouroullec and Paulillo (2010) add to this list other forms treated by literature as hybrid forms, namely: long-term contracts, manufacturing license agreements, and distribution and supply channels. According to Ménard (2004), cooperatives comprise a wide range of forms and therefore do not have a single point within the continuum. 
Although there is a diversity of forms, possible failures within these systems could still be observed, such as asymmetry in bargaining power between agents (Oliveira et al., 2015). Considering that market power can be concentrated in the retail link and that this affects producers, governance structures such as cooperatives arise as a way to increase the bargaining power of the producer link, in addition to promoting the exchange of knowledge between agents (Bijman, 2009; Corte et al., 2015; Lambrecht et al., 2015; Malorgio et al., 2012).

When it comes to superior quality attributes, this has historically been pointed out as one of the difficulties of cooperatives (Hanf, 2009), since several traditional practices in cooperatives do not meet market quality demands (Mérel et al., 2009). There is also the difficulty of incorporating heterogeneous producers and the ability of each of them to produce with high quality (Mérel et al., 2015).

Despite this, Bijman (2009) points out that cooperatives play an important role in coordinating activities to achieve quality, brand building, and innovation. This is because cooperatives can reduce the asymmetry of information from the definition of standards and different levels of quality. In addition, the participation of producers in cooperative organizations enables the sharing of risks, helping to reduce the possibility of losses in the face of specific investments (Bijman, 2009).

Cechin et al. (2013) explain that central or hierarchical decision-making allows cooperatives to define and apply quality standards for their supply, control the quality of delivered products, monitor the production of members, and even exclude a member from carrying out new deliveries. The authors suggest that the production practices of cooperative producers may result in a higher compliance rate and higher average quality.

Thus, we discussed the need to analyze cooperatives that operate with superior or differentiated quality products.

\section{Methodological Procedures}

This is a qualitative (Merriam, 1998), descriptive (Triviños, 1987) research. At first, we collected data to understand how the production chain of beef cattle is configured with a focus on differentiation. Then, we investigated the cooperative slaughterhouses operating in the state of Paraná.

For this purpose, we used secondary and primary data. As a secondary database, we used reports from the Brazilian Institute of Geography and Statistics (IBGE), the United States Department of Agriculture (USDA), the Ministry of Agriculture, Livestock and Supply (MAPA), the Brazilian Livestock Report (ANUALPEC), and documents made available by the cooperatives studied.

We collected the primary data through semi-structured interviews with three key agents who participated in the elaboration and execution of the beef cattle project of Paraná and/or supported the development of cooperatives (KA1; KA2; KA3). From the indication of the agents, we accessed the cooperative slaughterhouses.

For the choice of cooperatives, we sought, by accessibility criterion, to cover all those active in livestock farming aimed at some type of differentiation. According to the interviewees, there are currently seven cooperatives in the state (KA1; KA3). The study investigated six of them, here being called cooperative A, B, C, D, E, and F. We also carried out in loco observations in the cooperatives studied, which made it possible to monitor the negotiation processes. Figure 1 shows the location of the cooperatives studied. 


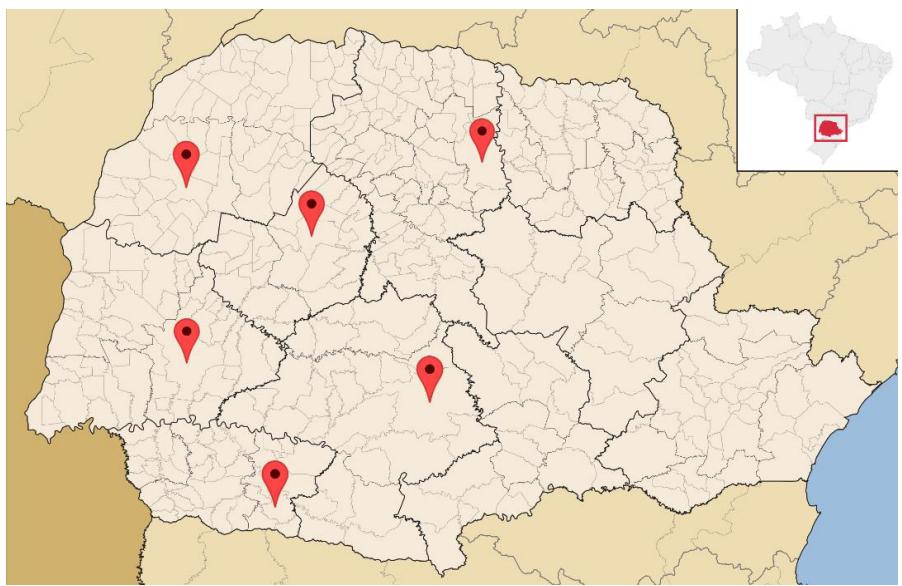

Figure 1. Location of the cooperatives studied. Source: elaborated by the authors from Abreu (2006).

Semi-structured interviews were conducted with representatives of cooperatives, according to Chart 1.

Chart 1 Respondents in the survey

\begin{tabular}{|c|c|c|}
\hline Cooperatives & Respondent & Denomination in the survey \\
\hline \multirow{3}{*}{ Cooperative A } & Zootechnician of the cooperative & CA1 \\
\hline & Cooperative veterinarian & CA2 \\
\hline & Administrator of the cooperative & CA3 \\
\hline \multirow{2}{*}{ Cooperative B } & Administrator of the cooperative & CB1 \\
\hline & Cooperative farm manager & CB2 \\
\hline \multirow{2}{*}{ Cooperative C } & Technical department manager & CC1 \\
\hline & Project coordinator of the technical department & $\mathrm{CC2}$ \\
\hline \multirow{2}{*}{ Cooperative D } & Administrator of the cooperative & CD1 \\
\hline & Manager of the supply company & CD2 \\
\hline Cooperative E & Administrator of the cooperative & CE1 \\
\hline Cooperative $\mathbf{F}$ & Administrator of the cooperative & CF1 \\
\hline
\end{tabular}

The interview script with key agents was divided into two parts. In the first, we investigated the process of creating the arrangements (alliances and cooperatives). The second sought information on each of the cooperatives studied, including forms of operation, advantages, and disadvantages.

The interview script with the cooperatives was divided into three parts. The first sought to understand the process of creation and functioning of cooperatives. The second focused on how transactions take place. And the third asked about the important characteristics of the transaction, including the ways of measuring, and monitoring the product.

Based on the elements of validity and reliability (Merriam, 1998), all interviews were recorded and subsequently transcribed for analysis. Data analysis was performed using the content analysis technique (Bardin, 1979). The categories were defined a prioribased on the literature studied, being: transaction attributes, dimensions involved in the transaction, and governance structure. The transaction attributes category was unfolded into the subcategories: asset specificity, frequency, and uncertainty.

Chart 2 is an analytical framework, showing the categories and subcategories of analysis, the operational definition of each of them, which are based on the constitutive definitions described in the theoretical framework, and some of the questions of the interview script that helped in the data collection. 
Chart 2. Analytical framework

\begin{tabular}{|c|c|c|c|}
\hline Analysis category & $\begin{array}{c}\text { Subcategories of } \\
\text { analysis }\end{array}$ & Operational definition & $\begin{array}{l}\text { Interview script } \\
\text { questions }\end{array}$ \\
\hline \multirow[t]{13}{*}{$\begin{array}{l}\text { Transaction } \\
\text { attributes }\end{array}$} & \multirow[t]{3}{*}{ Asset specificity } & \multirow{3}{*}{$\begin{array}{l}\text { - We analyzed it based on the possibilities } \\
\text { of negotiation of cattle with other buyers } \\
\text { besides the cooperative or in other markets } \\
\text { without a loss for the producer. We also } \\
\text { investigated the necessary investments or } \\
\text { changes in the property for production, } \\
\text { such as facilities, genetic improvement, and } \\
\text { research, courses, and training. }\end{array}$} & $\begin{array}{l}\text { - What efforts are needed } \\
\text { to initiate the transaction? } \\
\text { (investments, changes) }\end{array}$ \\
\hline & & & $\begin{array}{l}\text { - Can these efforts } \\
\text { (investments and changes) } \\
\text { be used in other activities? }\end{array}$ \\
\hline & & & $\begin{array}{l}\text { - If the transaction does not } \\
\text { occur with the cooperative, } \\
\text { are there losses for the } \\
\text { parties? Which ones? }\end{array}$ \\
\hline & \multirow[t]{5}{*}{ Frequency } & \multirow{5}{*}{$\begin{array}{l}\text { - We obtained it through the quantity and } \\
\text { regularity of transactions made over time } \\
\text { between cooperatives and producers, } \\
\text { including regularity of delivery and payment. }\end{array}$} & $\begin{array}{l}\text { - How long has the } \\
\text { transaction been going on? }\end{array}$ \\
\hline & & & $\begin{array}{l}\text { - Is there a turnover of } \\
\text { producers? }\end{array}$ \\
\hline & & & $\begin{array}{l}\text { - How long do you } \\
\text { renegotiate the sale? }\end{array}$ \\
\hline & & & $\begin{array}{l}\text { - What's the frequency of } \\
\text { delivery? }\end{array}$ \\
\hline & & & $\begin{array}{l}\text { - What are the payment } \\
\text { deadlines? }\end{array}$ \\
\hline & \multirow[t]{5}{*}{ Uncertainty } & \multirow{5}{*}{$\begin{array}{l}\text { - We investigated it through the inability } \\
\text { or difficulty in predicting future events in } \\
\text { the beef AGS and the differentiated beef } \\
\text { system, including behavioral aspects such as } \\
\text { trust or mistrust in exchange relationships; } \\
\text { and environmental characteristics such as } \\
\text { climatic influences or price fluctuations. } \\
\text { In addition, we analyzed the difficulties in } \\
\text { fulfilling the pre-established agreements. }\end{array}$} & $\begin{array}{l}\text { - Are there uncertainties } \\
\text { in the exchanges? Which } \\
\text { ones? [market, }\end{array}$ \\
\hline & & & behavioral] \\
\hline & & & $\begin{array}{l}\text { - Are uncertainties typical } \\
\text { of livestock farming? Or } \\
\text { are they typical of the } \\
\text { differentiated system? }\end{array}$ \\
\hline & & & $\begin{array}{l}\text { - How can uncertainties } \\
\text { disrupt the relationship? }\end{array}$ \\
\hline & & & $\begin{array}{l}\text { - What can hinder the } \\
\text { fulfillment of what has } \\
\text { been agreed between the } \\
\text { parties? }\end{array}$ \\
\hline \multirow[t]{4}{*}{$\begin{array}{l}\text { Dimensions } \\
\text { involved in the } \\
\text { transaction }\end{array}$} & \multirow[t]{4}{*}{-} & \multirow{4}{*}{$\begin{array}{l}\text { We analyzed which characteristics, attributes, } \\
\text { or important aspects for differentiated meat } \\
\text { transactions, whether these characteristics } \\
\text { are easy (more objective) or difficult (more } \\
\text { subjective) to specify and measure, and by } \\
\text { whom they are measured (sex, breed, age } \\
\text { of the animal and fat layer). In addition, we } \\
\text { investigated which of these characteristics } \\
\text { are most important for transactions in } \\
\text { cooperatives. }\end{array}$} & $\begin{array}{l}\text { - What product features } \\
\text { are important for the } \\
\text { transaction? }\end{array}$ \\
\hline & & & $\begin{array}{l}\text { - Are they pre-defined? } \\
\text { In writing or verbal } \\
\text { agreement? }\end{array}$ \\
\hline & & & $\begin{array}{l}\text { - How is it measured, } \\
\text { verified, controlled? By } \\
\text { whom? }\end{array}$ \\
\hline & & & $\begin{array}{l}\text { - Is there difficulty } \\
\text { in measuring the } \\
\text { characteristics? }\end{array}$ \\
\hline \multirow[t]{4}{*}{$\begin{array}{l}\text { Governance } \\
\text { structure }\end{array}$} & \multirow[t]{4}{*}{-} & \multirow{4}{*}{$\begin{array}{l}\text { They were specified based on how } \\
\text { the transactions are carried out in } \\
\text { the cooperatives, considering types } \\
\text { of agreements adopted (formal, duly } \\
\text { documented, or legally constituted contracts; } \\
\text { or informal, such as verbal agreements) for } \\
\text { the purchase and sale of livestock. }\end{array}$} & $\begin{array}{l}\text { - How does the transaction } \\
\text { happen? }\end{array}$ \\
\hline & & & $\begin{array}{l}\text { - What is established in a } \\
\text { written contract? }\end{array}$ \\
\hline & & & $\begin{array}{l}\text { - What is agreed verbally? } \\
\text { Can changes occur in what } \\
\text { has been agreed? }\end{array}$ \\
\hline & & & $\begin{array}{l}\text { - How does relational } \\
\text { matter? }\end{array}$ \\
\hline
\end{tabular}


To assist in the organization and categorization of data, we used the Atlas.TI@ software, specific for qualitative data analysis (ATLAS.ti, 2017). The following are the results and discussions.

\section{Data description and analysis}

The arrangements aimed at differentiation were, for the most part, first created as market alliances from the year 1998, and then transformed into cooperatives. To arrive at the current configuration, the interviewed agents KA1, KA2, and KA3 emphasize that several actions were developed over the years and that there were several difficulties, such as: difficulties in changing the behavior of agents, refrigerators did not pay for the quality and difficulty of the regularity of livestock supply.

Faced with difficulties, they discontinued some arrangements, but others have been developing and becoming examples for other states. According to the interviewees and based on secondary data, it was evident that there are seven cooperative slaughterhouses in operation, of which six were studied.

First, we described the functioning of cooperatives. Then, we discussed the attributes of the transaction and the measured dimensions. Finally, we debated the governance structure adopted.

\subsection{Operation of Cooperatives}

Cooperative A was created in 2005 and transformed into a cooperative at the end of 2008 (CA1). Cooperative A is classified as virtual, so it has no physical structure or employees; only a CNPJ, a bank account, a statute, and a board formed by the livestock farmers (CA3). A third-party company performs the administrative management of the cooperative (hereinafter referred to as Outsourced A). Despite being formally hired by Outsourced A, the interviewees were considered as representatives of the cooperative (CA1, CA2, and CA3), since, due to their performance, these roles are confused. Cooperative A has 27 livestock cooperates (CA2; CA3). It slaughters around 750 heads of cattle per month (CA1; CA3) and distributes the meat to about 18 municipalities (CA3).

Cooperative B was created in 2004 by 13 livestock farmers and transformed into a cooperative in 2005. To reach the legal minimum number of participants to form the cooperative, the farmers included other family members, totaling 22 people (CB1). Cooperative B bought a refrigerator, which makes it possible to slaughter animals of cooperates and partners (not cooperates). Cooperative B also leased a farm for fattening animals (CB2). The volume of slaughter is between 1,500 to 2,000 animals per month, which results in a volume of 375 to 500 tons of meat per month, but the cooperative has already slaughtered 3,500 animals per month (CB1). In 2016, Cooperative B begins a process of change of strategy from a partnership for certification of meat from a certain breed, aiming to increase the slaughter of differentiated meat and decrease the slaughter of "conventional" animals (CB1).

Cooperative $C$ begins to be designed from the year 1998 by a group of seven producers of German origin who were part of another agroindustrial cooperative of the central-south region of Paraná. It was the first marketing alliance created and became a cooperative in 2007 (CC1). We highlight that its action as an alliance and its pioneering work put it in a prominent place for the other organizations that emerged later. Cooperative $\mathrm{C}$ has about 50 employees to manage two projects: cattle and sheep. The entire logistic process of cattle search and meat delivery is 
carried out by the cooperative, which allows quality control from the farm to retail (CC1; CC2). Currently, there are about 130 cooperative producers.

The slaughter volume of Cooperative $C$ revolves around 22,000 animals per year and the slaughter service is outsourced (CC1), and they pay a fee for this service. Most of the slaughter is carried out in a partner refrigerator, whose partnership was formed from the very beginning when it was still an alliance. Although this refrigerator is not exclusive, CC1 cites that most of the slaughter is carried out for Cooperative $C$. As the structure of the refrigerator has space and volume restrictions, they also have a second partnership with a larger refrigerator that is almost $300 \mathrm{Km}$ from the headquarters of the Cooperative, aiming to increase the volume of slaughter. In 2012, Cooperative C partnered with a breed association to certify the animals and subsidize the meat from this breed (CC1). To date, Cooperative $\mathrm{C}$ is the only organization in Paraná certified by the program of this association (CC2).

Cooperative $D$ was founded in 2005 by 33 members. Of the organizations studied, it was the only one that has ever started to perform as a cooperative. The cooperative has 66 producers, and 32 of them active. The slaughter is done in a rented refrigerator, and the cooperative itself performs it. The cooperative sells half beef carcass, with a monthly production capacity of 630 heads, and its buyers are supermarkets in the western region of the state (CD1; CD2).

Cooperative E was created in 2003, from the union of four producers, which aimed to diversify rural activity to mitigate risks from agriculture. In 2008, the organization was formed as a cooperative. Currently, the organization has approximately 150 cooperates. Slaughter is carried out in a third-party refrigerator. Its buyers are supermarkets and butchers located throughout the state of Paraná, and the slaughtering capacity of the cooperative is 1,000 heads per month, being $90 \%$ of this value marketed in carcass form, and $10 \%$ in vacuum-packed cuts (CE1).

Cooperative $\mathrm{F}$ was founded in 2003, by 12 livestock farmers and formalized as a cooperative in 2007. Currently, it has about 63 producers, of which 30 actively deliver. An administrator manages the cooperative since 2013 and is therefore not one of the cooperate producers. Also, four employees are part of the board, including a veterinarian and a zootechnician who assist producers with technical support (CF1). The production capacity is 600 heads per month. The cooperative outsources the slaughter service. According to CF1, in all the slaughters, five employees of the cooperative carry out the follow-up.

Figure 2 shows the operation of the cooperatives.

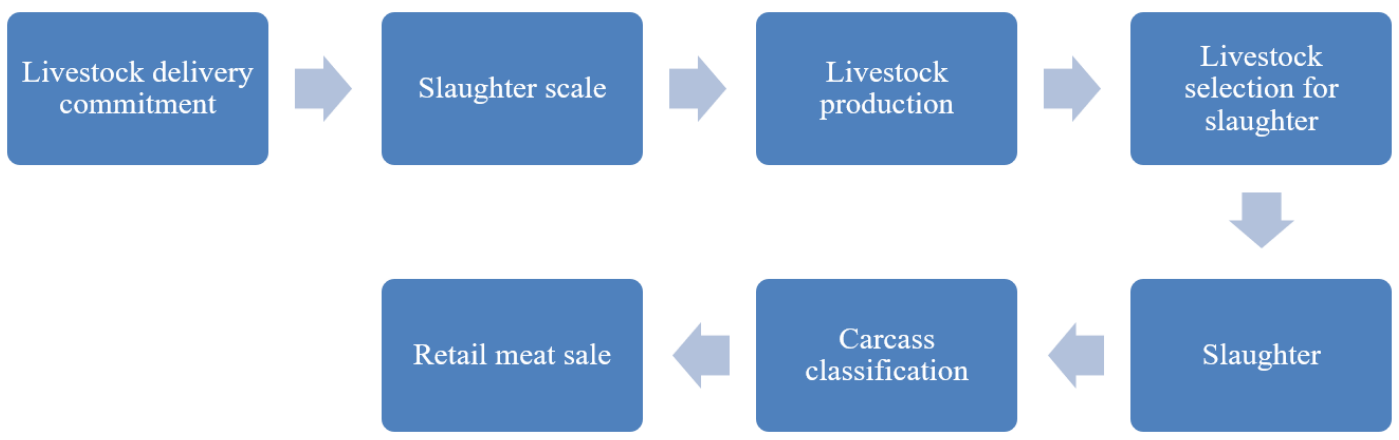

Figure 2. Operation of cooperatives. Source: Prepared by the authors.

In general, it is noted that the planning of cooperatives begins from the commitment of cattle delivery assumed by the farmers. This procedure can be formalized with a signed contract (C), by the commitment made and described in the minutes of the meeting ( $A$, $D$, and F), or informally, by the promise from the word of the producer $(B, E)$. From this data, cooperatives 
make a slaughter scale. The cattle farmers then carry out the production of the cattle to the standards required by each of the cooperatives, and the cattle is delivered to the refrigerator, according to the scale conducted. The cooperative technicians select the cattle for slaughter. After the slaughter, the technicians classify the carcass and then sell the meat to retail.

We observed that the main roles of cooperatives are the marketing of meat with a higher quality standard than the conventional market and the remuneration of livestock farmers for this higher quality. Chart 3 shows a summary of the characteristics of cooperatives.

Chart 3. Comparative summary of the characteristics of the cooperatives studied

\begin{tabular}{|c|c|c|c|c|c|c|}
\hline Cooperatives & A & B & C & D & $\mathbf{E}$ & $\mathbf{F}$ \\
\hline Slaughter structure & Outsourced & Own & Outsourced & Leased & Outsourced & Outsourced \\
\hline $\begin{array}{c}\text { Responsible for } \\
\text { shipment/transport } \\
\text { of animals }\end{array}$ & Cooperative & $\begin{array}{l}\text { Cattle } \\
\text { farmer }\end{array}$ & $\begin{array}{l}\text { Cattle } \\
\text { farmer }\end{array}$ & Cooperative & Cooperative & Cooperative \\
\hline $\begin{array}{l}\text { Technical monitoring } \\
\text { of the cooperative }\end{array}$ & Yes & No & Yes & No & Yes & Yes \\
\hline Fleet & Outsourced & Own & Own & Outsourced & Outsourced & Own \\
\hline Breed certification & No & Yes & Yes & No & No & No \\
\hline $\begin{array}{l}\text { Age and breed } \\
\text { flexibility }\end{array}$ & Yes & Yes & No & Yes & Yes & Yes \\
\hline $\begin{array}{l}\text { Remuneration for } \\
\text { regularity }\end{array}$ & No & Yes & Yes & No & No & No \\
\hline Retail performance & Regional & Regional & Statewide & Statewide & Regional & Regional \\
\hline
\end{tabular}

Regarding the slaughter structure, we identified that four cooperatives carry out the slaughter through a third-party refrigerator ( $A, C, E$, and F), while two cooperatives vertically integrated this step (B and $C$ ). In Cooperative $B$, respondents explain that the purchase of the structure occurred because the refrigerator that provided slaughter service began to see the cooperative as a competitor and decided to stop providing the service. Therefore, the cooperates began to lease a structure, which was later bought by them by the decision of the cooperates. In Cooperative D, the lease occurred due to the search for quality assurance in the slaughter process.

Their slaughter structure allows greater control of the slaughter process, which is a step that historically generates conflicts between the parties. The internalization of this step gives cooperatives greater control over the quality of the traded product. Due to the importance of quality control, even in cooperatives where the slaughter is outsourced, the technicians of the cooperatives monitor the process, in order to generate confidence in the yield of slaughter, which incurs monitoring costs. This cost, which in the conventional market is for the producer, goes to the cooperatives.

On the responsibility for the shipment and transportation of animals for slaughter, only in Cooperatives B and C, the livestock farmer is responsible for this. In the other, the cooperative is responsible for this step, involving monitoring costs to ensure the quality of animals by cooperatives.

As for the technical monitoring within the livestock farmers' properties, only Cooperatives $B$ and $D$ do not monitor them, while in the others this service is offered to all farmers. While monitoring helps to standardize the production process, there is also a monitoring cost.

When it comes to the transport of animals from farms to the refrigerator, Cooperatives B, C and $\mathrm{F}$ have their own fleet, which allows greater control over the problems arising from transport, 
such as injuries, weight loss, exhaustion, and stress and, consequently, over the quality of meat. In other cooperatives, the fleet is outsourced, which transfers responsibility for transportation to the livestock farmer.

Considering the breed certification, only Cooperatives B and C A have it. The option for the certification of the breed imposes new rules the cooperatives have to comply with, and the need to increase the volume of the slaughter of the chosen breed; this impacts on the functioning of organizations, since it tends to a greater formalization, as occurred in Cooperative $C$, in which the certification demanded an expansion in the number of cooperates and the need to create the contract of commitment of delivery. In Cooperative B, the certification is still recent, and the condition of its slaughter structure still allows some flexibility regarding the breeds.

Concerning the age and breed of the animal, it was found that most cooperatives make this issue more flexible, because, although the recommendation is for precocious animals (up to 24 months) and breeds with European crossings, such as Angus and Hereford, there is still negotiation for the slaughter of non-standard animals. Only Cooperative $\mathrm{C}$ has no flexibility regarding age and breed due to the requirements of the certifier, although it still slaughters other breeds, with value well below the certified one to discourage the production of other breeds.

Regarding remuneration for regularity, only Cooperatives B and C remunerate livestock farmers, which can be explained by the certification, since a volume of the slaughter of the certified breed is necessary.

Finally, concerning retail activity, we found that four cooperatives focus on regional activity, and only Cooperatives C and D operate throughout the state. This shows that there is still room for market prospecting, although the volume of slaughter is still a difficulty pointed out by agents for cooperatives.

In general, there are technical differences in the way cooperatives operate. In addition, we noted that the operation of cooperatives is quite different from the conventional market. Chart 4 shows the characteristics of the transaction in cooperatives and the conventional market, according to information from the agents interviewed.

Chart 4. Comparison of the characteristics of the transaction in the conventional market and the cooperative slaughterhouses studied

\begin{tabular}{|c|c|c|}
\hline Characteristics & Conventional Market & Cooperative slaughterhouses \\
\hline Negotiations & At each batch & Pre-determined \\
\hline Price & Market & Market + quality bonus \\
\hline Transport & On account of the refrigerator & $\begin{array}{l}\text { On account of the livestock } \\
\text { farmer or cooperative }\end{array}$ \\
\hline Sale of livestock & Live weight or dead weight & Deadweight \\
\hline Slaughter yield & $\begin{array}{l}\text { Pre-stipulated or after } \\
\text { slaughter }\end{array}$ & After slaughter \\
\hline Payment & Cash payment & $\begin{array}{l}\text { Cash; cash with discount or } \\
\text { installment payment }\end{array}$ \\
\hline By-products & From the refrigerator & From the Cooperative \\
\hline Remuneration for regularity & No & Yes \\
\hline
\end{tabular}

We can notice the differences between the transactions since in the conventional market each lot needs to be renegotiated with the market price of the day. The transport has been performed by the refrigerator, with the sale being finalized at live weight or dead weight, 
depending on the negotiation, which, in turn, involves the level of trust between the parties. The income tends to be pre-stipulated, the payment tends to be cash, the by-products are left to the refrigerator, which does not have the praxis of remuneration for quality, although, eventually, there are cases of negotiation for quality. On remuneration, in the conventional market, payment has prioritized yield (quantity).

On the other hand, in cooperatives, the trades are predetermined with market price plus a bonus for quality. Transportation can be at the expense of the livestock farmer or the cooperative. The sale of cattle is on deadweight and the yield is measured after slaughter. The payment can be in cash, with a discount, or in installments, and the by-products are left to the cooperatives, which pay the producer for different quality attributes, even if based on the minimum conditions required, such as the age of the cattle.

Considering the particularities in the functioning of slaughter cooperatives when compared to the conventional market, we sought to explore how the transactions between these cooperatives and producers are organized based on the attributes and dimensions involved in the transaction.

\subsection{Attributes and dimensions involved in the transaction}

The transaction between the livestock farmers and the cooperative slaughterhouses studied involves transaction-specific attributes that must be considered. Firstly, although the asset traded between the parties is cattle, both are concerned with the quality of the meat, which adds some complexity to the transaction.

Considering the specificity of assets, we observed in all cooperatives that there is the specificity of physical, human, temporal, and locational assets (Williamson, 1996). On the physical asset, although the interviewees insist that the investments made for the production of a precocious animal are necessary to modernize the cutting livestock and gain efficiency, such investments consist of irretrievable costs, if the cattle is not marketed with the cooperative. Regarding the specificity of human assets, it was noted that the production in this differentiated system required learning by livestock farmers about the way of production, management, nutrition, and breeds.

In the temporal specificity, it was found that the animal loses its differentiation characteristic if it is not slaughtered up to 24 months of age, and changes in both the loading date and time can generate losses in the value of the asset. In addition, the regularity of delivery is decisive for the realization of the transaction. We also observed the locational specificity in the transaction, since the location of the properties impacts it, both for transportation costs, and in the face of the displacement of animals for a long distance. The permanence of animals in transport for long distances can cause wear or stress of the animal and, consequently, leads to loss of quality.

In addition to the specificities common to all cooperatives, in Cooperative $C$, we identified brand specificity, according to Williamson (1996), since the certified breed of cattle is known worldwide in the meat market. The organization is the only authorized in the state of Paraná to market the meat of this breed with a quality seal.

Given the specificities described, bilateral dependence was found between the parties. Cooperatives depend on the supply of livestock, and livestock farmers depend on higher remuneration to invest in quality. This mutual dependence between the parties causes a recurrence in transactions, that is, as Williamson (1985) states, the parties matter.

Regarding frequency, we observed that regularity of delivery is essential for the transaction, although only Cooperatives B and C pay for regularity. However, failure to comply with the 
scale can culminate in moral sanctions, due to the relationship between the agents; and even the exclusion of a livestock farmer from the cooperative in more extreme cases.

In most cooperatives, there are no requirements in terms of minimum frequency and periodicity of delivery of animals by cooperates. Only Cooperative $\mathrm{C}$ mentioned a minimum required annual scale of 120 animals (CC1). This Cooperative also chose to offer to the cooperate a marketing contract, which makes it a cooperate with scale. In this case, when contracting, a quantity is formalized to be delivered by the livestock farmer and, in return, the cooperative offers a higher remuneration for the livestock marketed. As pointed out in the literature, this recurrence of the transaction and the scale involved justifying the contractual arrangement. As a protective mechanism regarding the supply, we verified the maintenance of uncooperative livestock farmers as partners.

The frequency of payment was also an important aspect noted. We identified that the entry into the cooperative provides a reduction of uncertainties regarding the guarantee of receipt. This is a behavioral uncertainty characteristic of the conventional beef system, as already identified by Caleman \& Monteiro (2013).

In terms of payment, Cooperative $\mathrm{C}$ makes the payment one day after the slaughter; Cooperatives B and D within seven days; Cooperative A within 28 days; and Cooperatives $\mathrm{E}$ and $\mathrm{F}$ within 30 days. In Cooperatives $\mathrm{A}, \mathrm{E}$ and $\mathrm{F}$ there is the option of cash payment with a $2 \%$ discount, depending on the financial availability of the cooperative. We noted that, in Cooperative $B$, the working time in the arrangement also influences the transaction, since the distribution of the leftovers of the cooperative is made considering the capital invested by the oldest members and the movement of cattle during the year (CB1).

As for uncertainty, climatic, behavioral, and market uncertainties were observed. With regard to climate, it was observed that, although the interviewees point to livestock as a safe activity compared to agriculture, climate changes impact the availability of inputs for animal feed and compliance with slaughter scales, and may generate losses in asset value. On behavioral uncertainties, they may be related to the fact that livestock farmers choose production only at times favorable to the purchase of inputs, compromising the scale of slaughter. Despite being an imminent possibility, this type of opportunistic behavior has not been observed in cooperatives, as reported by the agents interviewed.

About market uncertainties, despite the security of delivery in cooperatives, there is uncertainty as to the value to be received. Even in the differentiated system, the calculation of the value considers the price of the arroba of a fat ox in the conventional market, which can compromise the return of efforts in differentiation. In the same sense, we identified concerns with the stability of cooperatives and the conventional market, since these issues can harm the remuneration differentiated by quality in the face of market fluctuations. Another uncertainty that cooperates is subject to relates to the purchase of calves. Therefore, Cooperatives $C$ and $E$ have programs of inclusion of calf producers.

Regarding the measurement of dimensions, we observed that they are important for the transaction to guarantee the value between the parties. Despite this, they emphasized that the transaction occurs at the time of loading the animal on the farm (ex-ante), however, some measurements are only possible to be made after the slaughter (ex-post). The required dimensions and methods of measurement in the studied cooperatives follow the same structure and are arranged in Chart 5. 
Chart 5. Required dimensions and forms of ex-ante and ex-post measurement

\begin{tabular}{|c|c|c|c|c|}
\hline \multirow[b]{2}{*}{ Dimensions } & \multicolumn{2}{|c|}{ Ex ante } & \multicolumn{2}{|c|}{ Ex post } \\
\hline & Measurable & $\begin{array}{c}\text { Form of } \\
\text { measurement }\end{array}$ & Measurable & $\begin{array}{c}\text { Form of } \\
\text { measurement }\end{array}$ \\
\hline $\begin{array}{l}\text { Age of the } \\
\text { animal }\end{array}$ & $\begin{array}{c}\text { Easy } \\
\text { measurement }\end{array}$ & $\begin{array}{l}\text { Through the } \\
\text { teeth }\end{array}$ & $\begin{array}{c}\text { Easy } \\
\text { measurement }\end{array}$ & $\begin{array}{l}\text { Through the } \\
\text { teeth }\end{array}$ \\
\hline Sex & $\begin{array}{c}\text { Easy } \\
\text { measurement }\end{array}$ & Visual & N/A & N/A \\
\hline Breed & $\begin{array}{c}\text { Difficult } \\
\text { measurement }\end{array}$ & Visual & $\mathrm{N} / \mathrm{A}$ & N/A \\
\hline Animal weight & $\begin{array}{c}\text { Easy } \\
\text { measurement }\end{array}$ & Scale & N/A & N/A \\
\hline Carcass weight & N/A & N/A & $\begin{array}{c}\text { Easy } \\
\text { measurement }\end{array}$ & Scale \\
\hline $\begin{array}{l}\text { Conformation of } \\
\text { the animal }\end{array}$ & $\begin{array}{c}\text { Difficult } \\
\text { measurement }\end{array}$ & Visual & $\mathrm{N} / \mathrm{A}$ & $\mathrm{N} / \mathrm{A}$ \\
\hline $\begin{array}{l}\text { Conformation of } \\
\text { the carcass }\end{array}$ & N/A & N/A & $\begin{array}{c}\text { Easy } \\
\text { measurement }\end{array}$ & Visual \\
\hline Fat layer & $\begin{array}{c}\text { Difficult } \\
\text { measurement }\end{array}$ & Visual & $\begin{array}{c}\text { Easy } \\
\text { measurement }\end{array}$ & Visual \\
\hline $\begin{array}{l}\text { Regularity of } \\
\text { delivery }\end{array}$ & $\begin{array}{c}\text { Easy } \\
\text { measurement }\end{array}$ & Delivery history & $\mathrm{N} / \mathrm{A}$ & $\mathrm{N} / \mathrm{A}$ \\
\hline Animal health & $\begin{array}{c}\text { Easy } \\
\text { measurement }\end{array}$ & Invoices/Visual & $\begin{array}{c}\text { Easy } \\
\text { measurement }\end{array}$ & Visual \\
\hline
\end{tabular}

Considering the age of the animal, since it is a precocious calf, the maximum age allowed for slaughter is 24 months. This verification is carried out visually, by cooperatives and livestock farmers ex-ante, by checking the teeth of animals and can be confirmed ex-post, which, according to respondents, is easy to ascertain. Some cooperatives have already worked with super-precocious (age up to 18 months) and hyper-precocious animals (up to 14 months). Bonus for precocity was identified in Cooperatives A and C. Cooperative C, for the hyper-precocious animal, also verified by the date of birth.

Sex is classified as male or female, both by cooperatives and producers, visually ex-ante, which does not apply to ex-post. In general, male animals receive a higher value, following the differences of the conventional market. Male animals are usually not castrated due to the reduced slaughter time.

On the breed of the animal, cooperatives recommend animals of British breeds, although all cooperatives also slaughter other breeds. Cooperatives A, B, and C make remuneration differentiated by specific breeds. In Cooperatives B and C, which have breed certification, the amount paid for the certified breed is much higher than the amount paid for the other breeds. The producers and cooperatives verify all animals ex-ante visually. In cooperatives with certification, the certifier's technician makes this analysis and certifies the breed.

All agents interviewed believe that measuring the breed is easy for them. However, as the animals for slaughter are crossbred, they can acquire characteristics of both breeders, which culminates in different characteristics and depends on experience or specific knowledge to prove, that is, this attribute is difficult to measure. 
Regarding weight, livestock farmers and cooperatives measure the live animal (ex-ante) by weighing them on a scale. Cooperatives require different minimum weights, although we noticed that there is some flexibility in most of them regarding this issue. The cooperative performs the weighting of the carcass ex-post. The weight of the carcass is used to estimate the yield when comparing with the weight of the animal, which can generate conflicts, because, as Pascoal et al. (2011) discuss, the weight of the carcass is under the domain of the processor link.

In the cases studied, conflicts over income, according to respondents, are possible and do not interfere with the operation of the transaction. However, as observed by Barzel (2005), property right guarantee requires double measurement to reduce losses, which sets transaction costs for these transactions. In addition, injuries and other types of problems are removed from the carcass in the preparation process, impacting the final weight. Cooperatives B and C record photographs in case of any abnormality in the carcass. Cooperative $\mathrm{F}$ photographs the entire process of shipment and slaughter, making the photos available to the cooperates, including the photo of each carcass after the preparation, setting up additional transaction costs.

The conformation of the animal is analyzed ex-antevisually, which depends on the experience of the agents and does not guarantee the ex-post quality, that is, it can be considered difficult to measure. The conformation of the carcass, which includes an analysis of the proportion of meat, bones, and muscles, is easy to perform ex-post, despite the level of subjectivity that involves this assessment.

The fat layer, according to the agents, can be estimated by analyzing ex-ante the conformation of the animal, which is considered difficult to measure, because it does not guarantee that the layer is following the required specifications. Ex post, they confirm, visually, how many millimeters of fat the carcass has and whether the fat cover is uniform or not, which, according to the interviewees, is easy to ascertain. Despite this, they emphasized that the evaluation of what is uniform includes a level of subjectivity that can cause divergence.

Technically, there are objective parameters for measuring the level of fat (Bridi \& Constantino, 2009). Despite this, cooperatives usually do not use this measurement, because they believe that there is no need and rely on visual evaluation, which can open room for failures in the distribution of value. Cooperatives have different requirements for fat layers.

In the case of the regularity of delivery, a follow-up is carried out through delivery history, especially in Cooperatives B and C, in which it is remunerated. We could not identify the monitoring of the regularity of delivery in Cooperative $D$.

Finally, on animal health, the agents do not cite it as a requirement; since they are minimum requirements for carrying out the slaughter, they assume that all comply with the regulations. Ex-ante, livestock farmers issue the ATG (Animal Transport Guide), which has information on vaccines and tests carried out on animals. Also, Cooperatives $C$ and $E$ have a list of foods and medicines that are prohibited to animals, such as cottonseed.

In short, although the requirements and measurements are common, there are different levels of flexibility of the parameters, and each cooperative remunerates the livestock farmer differently. Chart 6 provides a summary of the attributes and dimensions involved in transactions. 
Chart 6. Summary of attributes and dimensions involved in transactions

\begin{tabular}{|c|c|c|c|c|c|c|}
\hline Cooperatives & A & B & C & D & E & $\mathbf{F}$ \\
\hline $\begin{array}{c}\text { Asset } \\
\text { specificity }\end{array}$ & $\begin{array}{l}\text { Physical; } \\
\text { human; } \\
\text { temporal; } \\
\text { locational } \\
\text { asset. }\end{array}$ & $\begin{array}{l}\text { Physical; } \\
\text { human; } \\
\text { temporal; } \\
\text { locational } \\
\text { asset. }\end{array}$ & $\begin{array}{c}\text { Physical; } \\
\text { human; } \\
\text { temporal; } \\
\text { locational; } \\
\text { brand asset. }\end{array}$ & $\begin{array}{l}\text { Physical; } \\
\text { human; } \\
\text { temporal; } \\
\text { locational } \\
\text { asset. }\end{array}$ & $\begin{array}{l}\text { Physical; } \\
\text { human; } \\
\text { temporal; } \\
\text { locational } \\
\text { asset. }\end{array}$ & $\begin{array}{l}\text { Physical; } \\
\text { human; } \\
\text { temporal; } \\
\text { locational } \\
\text { asset. }\end{array}$ \\
\hline Frequency & $\begin{array}{c}\text { Regularity } \\
\text { of UNPAID } \\
\text { delivery; moral } \\
\text { sanctions } \\
\text { for NON- } \\
\text { compliance } \\
\text { with the scale; } \\
\text { payment to } \\
\text { the livestock } \\
\text { farmer in } 28 \\
\text { days. }\end{array}$ & $\begin{array}{c}\text { Regularity of } \\
\text { paid delivery; } \\
\text { moral } \\
\text { sanctions } \\
\text { for NON- } \\
\text { compliance } \\
\text { with the scale; } \\
\text { payment to } \\
\text { the livestock } \\
\text { farmer in } 7 \\
\text { days; acting } \\
\text { time in the } \\
\text { arrangement. }\end{array}$ & $\begin{array}{c}\text { Regularity of } \\
\text { paid delivery; } \\
\text { moral } \\
\text { sanctions } \\
\text { for NON- } \\
\text { compliance } \\
\text { with the scale; } \\
\text { payment to } \\
\text { the livestock } \\
\text { farmer } 1 \\
\text { day after } \\
\text { slaughter; } \\
\text { possibility } \\
\text { of acquiring } \\
\text { marketing } \\
\text { contract. }\end{array}$ & $\begin{array}{c}\text { Regularity } \\
\text { of UNPAID } \\
\text { delivery; } \\
\text { moral } \\
\text { sanctions } \\
\text { for NON- } \\
\text { compliance } \\
\text { with the scale; } \\
\text { payment to } \\
\text { the livestock } \\
\text { farmer in } 7 \\
\text { days; }\end{array}$ & $\begin{array}{c}\text { Regularity } \\
\text { of UNPAID } \\
\text { delivery; moral } \\
\text { sanctions } \\
\text { for NON- } \\
\text { compliance } \\
\text { with the scale; } \\
\text { payment to } \\
\text { the livestock } \\
\text { farmer in } 30 \\
\text { days. }\end{array}$ & $\begin{array}{c}\text { Regularity } \\
\text { of UNPAID } \\
\text { delivery; moral } \\
\text { sanctions } \\
\text { for NON- } \\
\text { compliance } \\
\text { with the scale; } \\
\text { payment to } \\
\text { the livestock } \\
\text { farmer in } 30 \\
\text { days. }\end{array}$ \\
\hline Uncertainty & $\begin{array}{c}\text { Climatic; } \\
\text { behavioral; } \\
\text { market. }\end{array}$ & $\begin{array}{c}\text { Climatic; } \\
\text { behavioral; } \\
\text { market. }\end{array}$ & $\begin{array}{c}\text { Climatic; } \\
\text { behavioral; } \\
\text { market. }\end{array}$ & $\begin{array}{c}\text { Climatic; } \\
\text { behavioral; } \\
\text { market. }\end{array}$ & $\begin{array}{c}\text { Climatic; } \\
\text { behavioral; } \\
\text { market. }\end{array}$ & $\begin{array}{c}\text { Climatic; } \\
\text { behavioral; } \\
\text { market. }\end{array}$ \\
\hline $\begin{array}{l}\text { Measurable } \\
\text { dimensions }\end{array}$ & $\begin{array}{c}\text { Age; sex; } \\
\text { breed; weight; } \\
\text { conformation } \\
\text { of the animal; } \\
\text { conformation } \\
\text { of the carcass; } \\
\text { fat layer; } \\
\text { regularity } \\
\text { of delivery; } \\
\text { animal health. }\end{array}$ & $\begin{array}{c}\text { Age; sex; } \\
\text { breed; weight; } \\
\text { conformation } \\
\text { of the animal; } \\
\text { conformation } \\
\text { of the carcass; } \\
\text { fat layer; } \\
\text { regularity } \\
\text { of delivery; } \\
\text { animal health. }\end{array}$ & $\begin{array}{c}\text { Age; sex; } \\
\text { breed; weight; } \\
\text { conformation } \\
\text { of the animal; } \\
\text { conformation } \\
\text { of the carcass; } \\
\text { fat layer; } \\
\text { regularity } \\
\text { of delivery; } \\
\text { animal health. }\end{array}$ & $\begin{array}{c}\text { Age; sex; } \\
\text { breed; weight; } \\
\text { conformation } \\
\text { of the animal; } \\
\text { conformation } \\
\text { of the carcass; } \\
\text { fat layer; } \\
\text { animal health. }\end{array}$ & $\begin{array}{c}\text { Age; sex; } \\
\text { breed; weight; } \\
\text { conformation } \\
\text { of the animal; } \\
\text { conformation } \\
\text { of the carcass; } \\
\text { fat layer; } \\
\text { regularity } \\
\text { of delivery; } \\
\text { animal health. }\end{array}$ & $\begin{array}{c}\text { Age; sex; } \\
\text { breed; weight; } \\
\text { conformation } \\
\text { of the animal; } \\
\text { conformation } \\
\text { of the carcass; } \\
\text { fat layer; } \\
\text { regularity } \\
\text { of delivery; } \\
\text { animal health. }\end{array}$ \\
\hline
\end{tabular}

Given the data, we observe that considering the TCE, as the transactions involve high asset specificity, there is bilateral dependence between the parties and there is the need for expost adaptations of price and scale, according to the discussions of Williamson (1985), vertical integration would be the most appropriate governance structure. Similarly for the MCE, although it is possible to measure the attributes, the fact that some measurements are difficult to perform before the slaughter (at the time of the transaction) would justify the adoption of protective mechanisms, such as vertical integration, as discussed by Barzel (2005). That is, just the analysis by TCE and MCE does not explain the hybrid form of contract. In this case, the fact that they are cooperatives and involve long-term relationships and trust between producers make it possible to succeed in transactions, as discussed in the next topic.

\subsection{Adopted Governance Structure - Cooperatives}

The adopted governance structure is the hybrid form (Williamson, 1985), which involves various organizational forms, such as cooperatives. In the cases studied, this hybrid form is characterized by verbal agreements supported by formal documents, such as the statute of cooperatives, internal regulations, invoices, transport guides, terms of responsibility, manuals 
of cooperatives, and minutes of meetings. Although they are characterized as a hybrid, we identified, in consensus with Ménard (2018), that they have some differences among themselves, mainly in the levels of formality or flexibility of procedures, such as in technical follow-up and monitoring by cooperatives.

These differences in the levels of formality occur depending on the relationship between the agents involved in the cooperatives since the role of trust has proved to be important for transactions, as it influences the procedures and measurements performed. According to the agents, at the beginning of the operation of the arrangements, there was greater participation of producers in the monitoring of the slaughter and the measurements carried out. As the results of the measurements showed values within the expected by the producers, over time a relationship of trust was built, which allowed the loosening of the measurements; currently, the producers do not have the habit of monitoring the slaughter, they trust the measurements made visually and there are rarely conflicts about the measurements.

When disagreements occur, we found that arbitration through dialogue and communication between the parties are efficient mechanisms, and it is not necessary to resort to legal decisions. Thus, trust and reputation between the parties are important in reducing opportunistic behavior (Ménard, 2004) and, in turn, in guaranteeing economic rights.

In this context, we argue that the measurements made by cooperatives played an important role in building trust between the parties and for the distribution of value. The confidence, in turn, enabled the reduction of measurement costs in the face of loosening the measurements. This lies in the fact that producers were responsible for the shipment and transport of animals in Cooperatives B and C, because there was no technical monitoring in these cooperatives, and because of the trust in visual measurements. Only Cooperative F adopts narrower mechanisms of measurement during slaughter since it formally records all the characteristics of the cattle with photographs. Cooperatives B and C only photograph in case of abnormality, so as not to lose the confidence built.

Thus, we argue that, despite the feasibility of conflicts and disincentives to quality, which could compromise the functioning of the system, slaughter cooperatives have been developing based on long-term relationships and trust between agents, which is consistent with the findings of Oliveira et al. (2017). Despite this, it is worth noting that not all quality attributes are remunerated, such as the fat layer, which allows the possibility of failures in measurement parameters and could compromise the guarantee of property rights, according to Barzel (2005).

When it comes to product quality, we observed that cooperatives have achieved a level of standardization, although they report that producers are quite heterogeneous, following the discussions of Bijman (2009) and Mérel et al. (2015). In the cases studied, standardization seems to occur as a result of the exchange of information between agents and with the support of trust, since the interviewees report that the standards, which are defined verbally, have been followed.

In addition, we emphasize, as highlighted by the key agents interviewed and by the agents of the cooperatives, that the performance of cooperative slaughterhouses had a strong influence, both in terms of price and quality, in the meat market in the state of Paraná and even outside the state. This is because, from the entry of cooperatives into the market, according to them, consumers became more demanding, which eventually influenced the competitiveness of the market. This discussion converges with the findings of Cechin et al. (2013) on the higher compliance rate and higher average quality of cooperated producers.

Finally, we argue that the performance of cooperatives is different from the conventional market, bringing greater security to agents by reducing or mitigating the uncertainties of beef 
AGS. Among the advantages of operating in cooperatives, are: remuneration for quality; the possibility of planning slaughter scale; greater certainty of receipt of payment; less influence of seasonality in the prices practiced by cooperatives; and the by-products remain for the cooperative. However, there is a loss of autonomy in marketing, because the producer commits the regularity of delivery, even in market casualties.

\section{Conclusions}

Resuming the initial objective of discussing the governance structures adopted between livestock farmers and their cooperative slaughterhouses in the differentiated beef chain in the state of Paraná, we observed that all cooperatives have similar objectives and requirements, although there are differences in how each activity is carried out and in the levels of formality or flexibility. The fact that they were established as strategic alliances and then formalized as cooperatives added to the quality requirements and make these organizations distinct from other agricultural cooperatives since the entry of producers depends on the approval of the members and the framework at the required levels.

Transactions between producers and cooperatives are organized in hybrid forms, characterized by verbal agreements supported by formal documents. Although the transactions are recurrent and have been successful, we identified that they involve high asset specificity, depend on subjective measurements, and are still exposed to market uncertainties, which leaves room for the generation of conflicts and disincentives to quality. Thus, if on the one hand, the cooperatives favored the bargaining power of the cooperates, they allowed the commercialization with greater added value, showing themselves as a viable alternative if compared to the conventional market, on other, there are still weaknesses that can compromise the continuity of this system, such as the fact of relying on trust. This highlights the inherent complexity of the cooperative-type governance structure.

Given this scenario, based only on the precepts of TCE and MCE, they would not be sufficient to explain the success of cooperatives. However, the relational and reputational aspects associated with trust and partnership between the parties constitute elements that enable the reduction of transaction and measurement costs in these structures. For this, the measurements performed by cooperatives played an important role in building trust between the parties and for the distribution of value, at first. In a second moment, the confidence built enabled the reduction of measurement costs. Therefore, in theoretical terms, our results show that social aspects are important for performing economic transactions, influencing the adopted governance structure.

In practical terms, we argue that, although the uncertainties are mitigated in the cooperatives studied, they can compromise the continuity of this system. In addition, since not all cooperatives are rewarded for all of the quality attributes involved in the transaction, such as superprecocity and breed, the possibility of opportunistic behavior in the chain is imminent. Given this, we suggest more objective forms of measurement that ensure the standardization of processes.

In addition, we argue that, as transactions depend on the trust and reputation of the parties, these social issues require attention by agents in the conduct of relationships and their influence on transactions. Thus, the growth or development of cooperatives is linked to these social issues, a fact that is difficult to reproduce in different contexts.

Considering the issues observed, we suggest that future studies conduct an investigation focused on the trust between the parties in the differentiated beef chain, considering the vision of the livestock farmers who operate in this system. From the findings, we also observed that 
certification impacts the functioning of cooperatives and seems to be a way to formalize the system. Therefore, we suggest that future studies investigate the certification process and its influence in this market.

\section{References}

Abreu, R. L. (2006). Map of Paraná state. Recuperado em 18 novembro, 2019, de https:// commons.wikimedia.org/wiki/File:Parana_MesoMicroMunicip.svg

Augusto, C. A., Souza, J. P., \& Cario, S. A. F. (2014). Nova economia institucional: vertentes complementares. Revista Ibero-Americana de Estratégia, 13(1), 93-108.

Barbosa, L. C., \& Caleman, S. M. (2016). Sustentabilidade em sistemas agroindustriais: um estudo multicascos da carne bovina de Mato Grosso do Sul, Brasil. Organizações Rurais \& Agroindustriais, 18(4), 315-331.

Bardin, L. (1979). Análise de conteúdo. Lisboa: Edições 70.

Barzel Y. (2000). The role of contract in quality assurance. Current Agriculture, Food \& Resource Issues, 1, 1-10.

Barzel, Y. (2005). Organizational forms and measurement costs. Journal of Institutional and Theoretical Economics, 161, 357-373.

Bijman, J. (2009). Vertical coordination in the agrifood supply chain; structure and strategy of the agricultural cooperative. In D. Zylbersztajn \& O. Omta (Eds.), Advances in supply chain analysis in agro-food systems (pp. 55-87). Sao Paulo: Editora Singular.

Bouroullec, M. D. M., \& Paulillo, L. F. (2010). Governanças híbridas complementares aos contratos no comércio justo citrícola internacional. Gestão \& Produção, 17(4), 761-773.

Bridi, A. M., \& Constantino, C. (2009). Qualidade e avaliação de carcaças e carnes bovinas. In Anais do Congresso Parananense de Estudantes de Zootecnia. Londrina: UEL.

Caleman, S. M. D. Q., \& Zylbersztajn, D. (2012). Falta de garantias e falhas de coordenação: evidências do sistema agroindustrial da carne bovina. Revista de Economia e Sociologia Rural, 50(2), 223-242.

Caleman, S. M. Q., \& Monteiro, G. F. A. (2013). Should I go to court? An assessment of the role of the Judiciary in disputes between cattle raisers and meatpackers in Brazil. Revista ADM, 48(2), 208-221.

Caleman, S. M. Q., Monteiro, G. F. A., \& Hendrikse, G. (2017). Sustainable food chains: the role of collective action and government incentives. Organizações \& Sociedade, 24(83), 618-632.

Caleman, S. M. Q., Sproesser, R. L., \& Zylbersztajn, D. (2008). Custos de mensuração e governança no agronegócio: um estudo de casos múltiplos no sistema agroindustrial da carne bovina. Organizações Rurais \& Agroindustriais, 10(3), 359-375.

Cechin, A., Bijman, B., Pascucci, S., Zylbersztajn, D., \& Omta, O. (2013). Quality in cooperatives versus investor-owned firms: evidence from broiler production in Paraná, Brazil. Managerial and Decision Economics, 34(3), 230-243.

Centro de Estudos Avançados em Economia Aplicada - CEPEA. (2020, outubro 18). PIB do Agronegócio. Recuperado em 23 outubro, 2020, de http://www.cepea.esalq.usp.br/pib/.

Coase, R. H. (1937). The nature of the firm. Economica, 4(16), 386-405.

Corte, V. F. D., Waquil, P. D., \& Stiegert, K. (2015). Wheat industry: which factors influence innovation? Journal of Technology Management \& Innovation, 10(3) 
Farina, E. M. M. (2002). Consolidation, multinationalisation, and competition in Brazil: impacts on horticulture and dairy products systems. Development Policy Review, 20(4), 441-457.

Forest, M., Wosgrau, F., Forest, R., Lozano, B., \& Gonçalves, R. M. (2014). A bovinocultura de corte e a questão da certificação, no agronegócio brasileiro. In Anais do $2^{\circ}$ Seminário Internacional de Integração e Desenvolvimento Regional. Ponta Porã-MS: ECAECO.

Hanf, J. (2009). Challenges of a vertical coordinated business for cooperatives. Journal of Cooperative Studies, 42(2), 5-13.

Hooks, T., McCarthy, O., Power, C., \& Macken-Walsh, Á. (2017). A co-operative business approach in values-based supply chain: a case study of beef co-operative. Journal of Co-operative Organization and Management, 5(2), 65-72.

Instituto Paranaense de Assistência Técnica e Extensão Rural - IAPAR-EMATER. (2018, novembro 21). Projeto bovinocultura de corte - resumo executivo. Recuperado em 21 novembro, 2018, de http://www.emater.pr.gov.br/modules/conteudo/conteudo.php?conteudo=63http:// www.sistemafaep.org.br/wp-content/uploads/2015/08/Bl13141.pdf

Joskow, P. L. (2004, setembro). New institutional economics: a report card. In Proceedings of the Conference of International Society of New Institutional Economics. Cambridge: MIT Economics. Recuperado em 17 fevereiro, 2016, de http://economics.mit.edu/files/1171

Lambrecht, E., Kühne, B., \& Gellynck, X. (2015). Asymmetric relationships in networked agricultural innovation processes. British Food Journal, 117(7), 1810-1825.

Macedo, L. O. B. (2015). The role of social capital for the governance of hybrid forms in agribusiness: an analysis of Brazilian beef alliances. Evolutionary and Institutional Economics Review, 12(2), 307-327.

Macedo, L. O. B., \& Moraes, M. A. F. D. (2009). Perfil de governança e a coordenação de alianças estratégicas da carne bovina brasileira. Informações Econômicas, 39(3)

Malorgio, G., Camanzi, L., \& Grazia, C. (2012). Supply chain relationships and quality certification schemes: a case study in fisheries. Politica Agricola Internazionale, 1, 63-80.

Ménard, C. (2004). The economics of hybrid organizations. Journal of Institutional and Theoretical Economics, 160(3), 345-376.

Ménard, C. (2018). Organization and governance in the agrifood sector: How can we capture their variety? Agribusiness, 34(1), 142-160.

Mérel, P. R., Saitone, T. L., \& Sexton, R. J. (2009). Cooperatives and quality-differentiated markets: strengths, weaknesses and modelling approaches. Journal of Rural Cooperation, 37(2), 201-224.

Mérel, P., Saitone, T. L., \& Sexton, R. J. (2015). Cooperative stability under stochastic quality and farmer heterogeneity. European Review of Agriculture Economics, 42(5), 765-795.

Merriam, S. B. (1998). Qualitative research and case study applications in education. United States of America: PB Printing.

Oliveira, T. E., Gianezini, M., Peripolli, V., \& Barcellos, J. (2015). Alianças mercadológicas e estratégias de diferenciação na cadeia da carne bovina no Brasil. Revista Ibero-Americana de Estartégia, 14(2), 40-50.

Oliveira, G. M., Caleman, S. M. Q., Cunha, C. F., \& Puperi, M. (2017). Value appropriation in Brazilian cattle industry. British Food Journal, 119(9), 2089-2101.

Oliveira, G. M., Cunha, C. F., Caleman, S. M. Q., \& Maia, R. L. G. (2019). Information assymetry: the case of cattle supply transaction in Brazil. British Food Journal, 121(8), 1825-1837. 
Pascoal, L. L., Vaz, F. N., Vaz, R. Z., Restle, J., Pacheco, P. S., \& Santos, J. P. A. (2011). Relações comerciais entre produtor, indústria e varejo e as implicações na diferenciação e precificação de carne e produtos bovinos não-carcaça. Revista Brasileira de Zootecnia, 40, 82-92.

RIC Mais. (2015). Ric Rural: Novos rumos da pecuária no Paraná. RIC-RURAL. Confira como funcionam as cooperativas de carne no Paraná. Grupo RIC Recuperado em 01 de setembro, 2016, de https://ruralpecuaria.com.br/agrovideo/ric-rural-novos-rumos-da-pecuaria-doparana.html/

Rocha, J. C. M., Neves, M. F., \& Lobo, R. B. (2001). Experiências com alianças verticais na coordenação da cadeia produtiva da carne bovina no Brasil. In Anais do Congresso Internacional de Economia e Gestão de Negócios. Ribeirão Preto: FEA-USP.

Saab, M. S. B. L. M., Neves, M. F., \& Cláudio, L. D. G. (2009). O desafio da coordenação e seus impactos sobre a competitividade de cadeias e sistemas agroindustriais. Revista Brasileira de Zootecnia, 38(supl. especial), 412-422.

Saes, M. S. M. (2009). Estratégias de diferenciação e apropriação de quase-renda na agricultura: a produção de pequena escala. São Paulo: Annablume, Fapesp.

Shanoyan, A., Bankuti, S. M. S., \& Colares-Santes, L. (2019). Analysis of incentive structures at producer-processor interface of beef supply chain in Brazil. Journal of Agribusiness in Developing and Emerging Economies, 9(2), 159-174.

Siffert Filho, N. F., \& Faveret Filho, P. S. C. (1998). O sistema agroindustrial de carnes: competitividade e estruturas de governança. Revista do BNDES, 5(10), 265-297.

Sornberger, G. P., Redivo, A., \& Redivo, A. R. (2010). Sistemas de certificação de alimentos: o caso da carne no Brasil. INGEPRO - Inovação, Gestão \& Produção, 2(5). Recuperado em 15 de julho, 2021, de https://econpapers.repec.org/paper/agsaesc15/204229.htm.

Tóth, J. (2015, abril). Value creation and capturing: the case of the Hungarian agri-food SMEs. In Proceedings of the 89th Agricultural Economics Society Conference. Coventry, UK: Agricultural Economics Society.

Triviños, A. N. S. (1987). Introdução à pesquisa em ciências sociais: a pesquisa qualitativa e, educação. São Paulo: Atlas.

Ueno, R. K. (2016). Alianças estratégicas na bovinocultura de corte: o caso das cooperatias de pecuaristas do Paraná, (Tese de doutorado). Universidade Federal do Rio Grande do Sul, Porto Alegre.

United States Department of Agriculture - USDA. (2020, outubro 23). Foreign agricultural services. Recuperado em 23 de outubro, 2020, de http://apps.fas.usda.gov/psdonline/psdQuery.aspx

Williamson, O. E. (1985). The economic institutions of capitalism. New York: Free Press.

Williamson, O. E. (1991). Comparative economic organization: the analysis of discrete structural alternatives. Administrative Science Quarterly, 36(2), 269-296.

Williamson, O. E. (1996). The mechanisms of governance. New York: Oxford University Press.

Zylbersztajn, D. (2005). Papel dos contratos na coordenação agro-industrial: um olhar além dos mercados. Revista de Economia e Sociologia Rural, 43(3), 385-420. 